\title{
DUKUNGAN KELUARGA DALAM PEMENUHAN KEBUTUHAN SPIRITUAL PASIEN DI RUANG ICU RSUD dr.M.YUNUS BENGKULU
}

\author{
Tuti Anggriani Utama, Livi Rahma Dana Yanti \\ Prodi D 3 Keperawatan FMIPA Universitas Bengkulu \\ Email: tautama@unib.ac.id
}

Kebutuhan spritual pada pasien kritis sangat penting karena dapat mempengaruhi proses penyembuhan akan penyakit yang dideritanya. Keluarga dapat menjadi sebagai fasilitator dalam memberikan kebutuhan spiritual bagi pasien. Namun permasalahan yang terjadi dukungan spiritual yang di lakukan keluarga masih sering diabaikan. Hasil wawancara terhadap 7 keluarga pasien yang menjaga pasien di ICU, 5 keluarga mengatakan kadang kadang mengingatkan pasien untuk berdzikir, untuk berdoa dan mengingatkan waktu sholat. 2 keluarga mengatakan selalu memotivasi pasien untuk berdoa dan mengingat Allah SWT dalam proses penyembuhannya. Penelitian ini bertujuan mengidentifikasi dukungan keluarga dalam pemenuhan kebutuan spritual pasien diruangan Intensive RSUD. dr.M.Yunus Bengkulu. Penelitian observasi analitik melalui metode cross sectional ini melibatkan 30 keluarga yang sedang mendampingi pasien di ICU yang diambil dengan accidental sampling. Data dikumpulkan dengan cara observasi menggunakan instrument. Analisa data menggunakan distribusi frekuensi dan persentase. Hasil yang didapatkan selama 2 minggu penelitian terdapat $84 \%$ dukungan keluarga kategori baik dalam pemenuhan kebutuhan spiritual pasien dan $16 \%$ kurang baik dalam pemenuhan kebutuhan spiritual pasien. Penelitian ini menunjukkan bahwa pentingnya pemenuhan kebutuhan spiritual bagi pasien dalam proses penyembuhan.

\section{Kata kunci : dukungan keluarga ICU, kebutuhan spiritual}

\section{Family Support In Fulfilling Patients 'Spiritual Needs In Icu Room, RSUD. dr, M.Yunus Bengkulu}

\begin{abstract}
Spiritual needs in critical patients is very important because it can affect the healing process of the disease they suffer. Family can become a facilitator in providing spiritual needs for patients. But the problem that occurs in the form of spiritual support that the family still often ignored. The results of interviews with 7 families of patients who take care of patients in the ICU, 5 families said - sometimes reminded patients to dhikr, to pray and remind the prayer time. 2 families said that they always motivate patients to pray and remember Allah in the healing process. This study aims to identify family support in fulfilling patients' spiritual needs in the Intensive Hospital. Dr. M. Yunus Bengkulu. This analytic observational research through cross sectional method involved 30 families who were accompanying patients in ICU taken by accidental sampling. Data collected by observation using instruments. Data analysis uses frequency and percentage distributions. The results obtained during the 2 weeks of the study found $84 \%$ of family support categories both in meeting the spiritual needs of patients and $16 \%$ less good in meeting the spiritual needs of patients. This research shows that the importance of fulfilling spiritual needs for patients in the healing process.
\end{abstract}

Keywords: ICU family support, spiritual needs 


\section{Pendahuluan}

Kondisi kritis yang dialami pasien di intensive care unit (ICU) banyak menimbulkan permasalahan psikologis bagi pasien dan keluarga. Dampak dari kondisi tersebut menimbulkan ketidakberdayaan dan keputusaan dalam proses penyembuhan sehingga pasien mengalami distress spiritual seperti pasien tidak melakukan ibadah dan menyalahkan tuhan sehubungan dengan penyakit yang dideritanya (Sriyono, 2019).

Pemenuhan kebutuhan spiritual tidak hanya dilakukan perawat namun keluarga juga dapat memberikan kebutuhan spiritual (Balboni dkk, 2013). Hidayat (2009) mengatakan keluarga mempunyai peran dalam pemenuhan kebutuhan spiritual karena keluarga memiliki suatu ikatan emosional dan berinteraksi selalu dalam kehidupan seharihari.

Dukungan keluarga sangat diperlukan bagi pasien karena dapat membantu dalam aktivitasnya sehingga dapat membantu permasalahan yang sedang terjadi pada dirinya seperti masalah pemenuhan kebutuhan spiritual dan dukungan tersebut akan berdampak positif bagi pasien selama mengahadapi proses sakit (Misgiyanto \& Susilawati, 2014). Dukungan keluarga adalah suatu bentuk hubungan interpersonal yang meliputi sikap, tindakan dan penerimaan terhadap anggota keluarga.

Dukungan keluarga dalam pemenuhan kebutuhan spiritual yang dapat dilakukan adalah berdoa bersama untuk pasien, meyakinkan pasien dan memotivasi untuk kesembuhan mengajak rohaniawan untuk membimbing spiritual pasien. Apabila hal ini dilakukan maka berefek positif pada psikologis dan kesejahteraan fisik sehingga pasien dapat menerima kondisinya, nyaman dan memberikan rasa damai dalam menuju kematian (Sriyono, 2019).

Dukungan spiritual juga dapat meringankan kondisi psikologis keluarga seperti takut, syok, putus asa, marah, cemas, dan depresi. Selain itu melalui dukungan spiritual yang baik akan mampu meningkatkan kualitas hidup pasien dan membatu keluarga dalam menghilangkan rasa takut dengan keadaan salah satu keluarganya yang sedang terbaring sakit dan tidak sadarkan diri.

Kebutuhan spiritual juga bertujuan untuk mempertahankan atau membalikan keyakinan dan untuk mendapatkan manfaat atau pengampunan, mencintai, menjalani hubungan penuh rasa percaya dengan tuhan. Kebutuhan spiritual sebagai bagian dari kebutuhan manusia secara utuh hanya dapat dipenuhi apa bila perawat dibekali dengan kemampuan diberikan asuhan keperawatan dengan memperhatikan aspek spiritual sebagai bagian dari kebutuhan pasien sebagai makhluk hidup yang utuh dan unik.

Keluarga juga dapat memberikan keyakinan pada pasien bahwa penyakit yang diderita bukan merupakan suatu hukuman atau siksaan yang diberikan Tuhan melainkan suatu cobaan untuk menguji keimanan dan ketabahan. Dukungan spiritual keluarga berdampak pada peningkatan rasa percaya diri pada penderita dalam menghadapi proses pengobatan penyakitnya (Tuti, 2015). Hasil penelitian Balboni dkk (2013), bahwa dukungan spiritual yang didapatkan untuk meningkatkan kualitas hidup sebesar (43\%).

RSUD. dr. M. Yunus Bengkulu merupakan satu-satunya rumah sakit rujukan Provinsi Bengkulu yang memiliki ruangan intensive (ICU, ICCU, PICU, NICU). Hasil wawancara terhadap 10 keluarga pasien yang menjaga pasien di ICU, 5 keluarga mengatakan kadang-kadang mengingatkan pasien untuk 
berdzikir, untuk berdoa dan mengingatkan waktu sholat. 2 keluarga di ICU mengatakan selalu memotivasi pasien untuk berdoa dan mengingat Allah SWT dalam proses penyembuhannya. 1 pasien yang sudah mengalami peningkatan kesadaran mengatakan bahwa selama tidak sadar pasien merasakan sakit saat menggunakan ventilator dan menyalahkan tuhan atas sakit yang dideritanya. 1 orang juga mengatakan bahwa tidak ada keyakinan untuk sembuh karena sudah 7 hari di ruangan ICU dengan penuurunan kesadaran. 1 orang lagi sudah 5 hari dirawat di ICU selalu punya keyakinan untuk sembuh dan selalu berdoa.

Berdasarkan uraian diatas maka penulis tertarik untuk mengidentifikasi bagaimanakah gambaran dukungan keluarga dalam pemenuhan kebutuhan spiritual pasien di ruangan ICU di RSUD.dr.M.Yunus Bengkulu.

\section{Metode Penelitian}

Penelitian observasi analitik melalui metode cross sectional ini melibatkan 30 keluarga yang sedang mendampingi pasien di ICU yang diambil dengan accidental sampling. Data dikumpulkan dengan cara observasi menggunakan instrument. Kuesioner ini berfungsi untuk mengetahui bagaimana dukungan keluarga terhadap pemenuhan kebutuhan spiritual pada pasien kritis di ICU. Instrument dalam penetian ini dibuat oleh Siregar (2015) Kuesioner ini terdiri dari 25 pernyataan dengan pilihan jawaban selalu, sering, kadang kadang, dan tidak pernah. Setiap item yang dijawab akan diberi nilai yaitu Selalu diberi nilai 4, Sering diberi nilai 3, Kadang-kadang diberi nilai2, tidak pernah diberi nilai 1.

Dimana P merupakan panjang kelas dan rentang kelas adalah nilai tertinggi dikurang nilai terendah. Jumlah skor tertinggi yang akan didapat adalah 100 dan skor terendah adalah 25. Jadi, rentang kelas sebesar 75 dan banyak kelas 3 yaitu baik, cukup dan kurang sehingga diperoleh $\mathrm{P}=25$. Maka dukungan keluarga dikategorikan baik jika mampu menjawab pernyataan dengan skor 76-100, cukup 51 - 75, dan kurang 25- 50. Berdasarkan jumlah 30 reponden, maka nilai $r$ tabel yang ditetapkan adalah 0,361 . Penelitian ini dilakukan uji valid pada kuesioner dengan jumlah 25 item dan didapatkan hasil adalah semua 24 item valid dengan nilai tertinggi 0,762 dan nilai valid dengan nilai terendah 0,377 dan 1 item tidak valid (nomor 17) dengan nilai 0,271 dan item yang tidak valid tidak digunakan pada penelitian ini dan Hasil uji reliabilitas yang dilakukan peneliti kepada 30 orang keluarga pasien mendapatkan nilai 0,896 . Dengan nilai 0,896 terbukti bahwa kuesioner tersebut reliabel.

Analisa data menggunakan distribusi frekuensi dan persentase.

\section{Hasil Penelitian dan Pembahasan Hasil Penelitian}

Hasil penelitian yang meliputi gambaran secara umum responden (jenis kelamin, usia, tingkat pendidikan, pekerjaan, agama, hubungan dengan pasien) dan data kasus yang berkaitan dengan dukungan pemenuhan kebutuhan spiritual pasien di ruang Intensive care unit (ICU). Proses pengumpulan data dilakukan dengan cara mengobservasi keluarga pada jam besuk/jam kunjungan yaitu, pagi hari jam 11.0012.00 wib dan hari jam 17.00-18.00 wib sore setelah responden bersedia menjadi sampel penelitian. Penelitian ini dilakukan di Ruang ICU RSUD dr.M,Yunus Bengkulu pada 2 Mei s/d 17 Mei 2018. Jumlah sampel dalam penelitian ini sebanyak 30 sampel. Dukungan keluarga dalam pemenuhan kebutuhan spiritual pasien di ruang ICU berada d kategori baik 25 orang (84\%), dan kurang baik 5 orang (16\%). 


\section{Pembahasan}

Hasil penelitian dari observasi menunjukan $83 \%$, dukungan keluarga dalam pemenuhan kebutuhan spiritual baik. Hal ini dapat terjadi dikarenakan keluarga mempunyai pengetahuan yang baik terhadap kebutuhan spiritual bagi pasien dengan kondisi di ICU, Kelurga juga berpendapat bahwa spiritual mempunyai arti religi karena melalui spiritual pasien dapat berdoa, mempunyai semangat hidup serta dapat menerima rasa sakit yang dialaminya. Menurut Bussing et al (2010) kebutuhan spiritual pada dimensi eksistensi diri menjadi kebutuhan spiritual. Kebutuhan spiritual meliputi refleksi kehidupan, berbicara dengan seseorang tentang kehidupan setelah kematian. Menurut Fankl dalam Guillory et al, (1997), inti keberadaan manusia (eksistensi melalui pencarian makna dan tujuan hidup. Dalam penelitian ini esensi dari keberadaan pasien juga menunjukkan adanya tujuan hidup yang didapatkan oleh pasien selama sakit. Menurut Walton (2002) spiritualitas adalah keseimbangan setelah seseorang mendapatkan bantuan pada saat kondisi kritis.

Kebutuhan spiritual merupakan kebutuhan yang penting di penuhi pada pasien yang dirawat di ICU. Keluarga mempunyai koping yang baik dalam pemenuhan spiritual Hal ini dikarenakan (membaca doa untuk pasien ketika jam kunjungan keruangan), yang menggunakan peryataan dari 30 keluarga pasien ada 25 keluarga yang menberikan doa untuk pasien. Hal ini dikarenakan hampir semua keluarga dari pasien beragama Islam, sehingga hal ini tentu saja sangat mendukung keluarga dalam pemenuhan spiritual pasien. Adanya dukungan keluarga yang selalu diberikan kepada pasien seperti; memberikan motivasi dengan mengajarkan dan mengingatkan pasien untuk melaksanakan ibadah berdoa pada saat jam kunjungan yang sudah ditentukan. berdoa dapat memberikan rasa damai, tenang, dan membantu proses kesembuhan. Rasa damai dan tenang membuat diri dalam keadaan rileks, sehingga pembuluh darah menjadi rileks. Ini memberi perasaan damai dan tenang dapat membantu proses penyembuhan dan tidak memperparah kondisi pasien. Hal itu, penyembuhan suatu penyakit tidak hanya dipengaruhi oleh obat saja, namun juga dipengaruhi oleh keyakinan spiritual. Sejalan dengan pendapat Arifin (2013) bahwa pasien kritis tidak hanya menderita penyakit fisik, akan tetapi mengalami masalah psikologi. Jika, masalah psikologi dibiarkan akan menimbul kan dampak yang merugikan bagi pasien serta mengakibatkan adanyatekanan dan gangguan seperti marah, stress, rasa putus asa, tidak berdaya dan takut datangnya kematian. Hal ini didukung oleh Ibrahim dkk (2014) bahwa berdoa ada dapat membantu seseorang dalam mencari jati diri sehingga dapat membantu menjawab tentang kehidupan seseorang yang berhubungan dengan TuhanNya. Secara keseluruhan responden penelitian ini berjenis kelamin perempuan 18 orang, dan lakilaki 12 orang sebanyak 25 orang dapat memenuhi kebutuhan spiritual pasien dengan baik.Hasil penelitian ini pasien kritis pada paling banyak perempuan, sehingga mayoritas keluarga yang merawat adalah perempuan, dari hubungan dengan pasien paling banyak adalah ibu dan suami/istri adalah orang yang paling dekat dengan ibu dan istri di dalam sebuah keluarga (Friedman, 2013).

Hasil penelitian menunjukan $16 \%$ keluarga tidak baik dalam memberikan dukungan spiritual pasien yaitu (membaca doa untuk pasien ketika jam kunjungan keruangan), ini biasanya disebabkan oleh salah satunya karena usia semakin dewasa umur seseorang maka semakin logis dalam berpikir berdasarkan penelitian 
menunjukan bahwa responden dengan Usia 60-69 tahun merupakan usia dewasa tua dalam keterlibat dalam masyarakat dan bersosialisasi. Departemen Kesehatan Republik Indonesia mengemukakan usia dewasa kurang memberikan dukungan yang maksimal untuk pasien (DepKes RI, 2009). Friedman (2014) juga menyatakan bahwa usia merupakan faktor utama yang mepengaruhi struktur peran dalam pemberian asuhan keperawatan keluarga, sehingga kedewasaan usia seseorang maka dukungan keluarga yang diberikan akan semakin turun karena semakin dewasa seseorang maka dia akan mengalami penurunan bersosialisasi. Menurut Potter \& Perry (2007) bahwa pada usia dewasa tengah memiliki tugas untuk merawat dan membimbing orang lain, selain itu dimana pada usia 20-29 tahun seorang anggota keluarga lebih perhatian pada anggota keluarganya sehingga dukungan yang diberikan lebih baik. Pada satu penelitian, peneliti menemukan bahwa individu produktif yang menganut agama dan aliran spiritual serta berpartisipasi dalam kegiatan keagamaan dilaporkan memiliki kesehatan fisik yang lebih baik (Rahmawati, 2015). Penelitian ini sudah sejalan dengan penelitian yang dilakukan oleh Susanti \& Sulistyarini (2013), menyatakan bahwa usia merupakan faktor penentu tahap perkembangan seseorang sehingga rentang usia memiliki pemahaman dan respon terhadap perubahan kesehatan yang berbeda-beda. Keluarga (menanyakan kepada perawat atau dokter mengenai hal yang dibutuhkan pasien dan kondisi perkembangan kesehatan pasien), dari 30 keluarga, 27 orang keluarga hamper setiap hari menanyakan kondisi dan perkembangan pasien, hal ini disebabkan karna dari keluarga pasien hampir semuanya berpendidikan tamatan SD. Ini bisa menyebabkan salah satunya adalah faktor karena faktor tingkat pendidikan dapat mempengaruhi pemahaman akan kemampuan berpikir. Hasil dari penelitian diatas berbanding terbalik dengan hasil penelitian Menurut Notoadmojo (2013),
Semakin tinggi tingkat pendidikan seseorang semakin mudah menerima informasi dan semakin baik pengetahuan yang dimiliki. Penelitian yang dilakukan oleh Ningtyas (2013), menyatakan bahwa pendidikan merupakan faktor penting dalam memahami penyakit, pengelolaan diri, dan perawatan termasuk yang diderita anggota keluarga, sehingga pendidikan SD diyakini belum dapat melakukan perawatan kepada pasien. Karena kurangnya pengetahuan dari keluarga pasien. Keluarga pasien yang datang pada jam kunjungan, (memberi sentunhan yang penuh perhatian kepada pasien ketika jam kunjungan) yang memilih pernyataan ada 30 pasien ini biasanya disebabkan oleh salah satu dikarenakannya status sosial ekonomi. Berdasarkan penelitian pekerjaan keluarga pasien mayoritas menunjukkan bahwa dari 30 responden diperoleh mayoritas adalah petani 13 orang $(43 \%)$. Ini dikarenakan status pekerjaan memberikan dampak langsung pada dukungan keluarga, apabila penghasilan yang didapatkan kurang atau tidak ada, maka akan mempengaruhi dukungan untuk menunjang pemberian dukungan untuk kesembuhan pasien (Friedman, 2013). Penelitian ini sama dengan penelitian yang dilakukan oleh Rahmawati (2015) yang dilakukan di Ruang ICU RSUD dr Pirngadi dengan hasil dari 20 responden diperoleh mayoritas pekerjaan keluarga pasien adalah wirausaha. Keluarga, (membaca kitab suci alquran untuk pasien ketika jam kunjungan keruangan ), dari 30 keluarga 15 orang keluarga membacakan ayat suci alquran, hal ini disebabkan karna dari keluarga pasien hampir semuanya beragama islam. Hasil penelitian ini juga menunjukan bahwa jumlah responen dalam pemenuhan kebutuhan spiritual pasien mayoritas 
beragama islam 29 orang (96\%). dan satu orang pasien menganut agama budha, pada agama budha keluarga meberikan dukungan keluarga dalam pemenuhan kebutuhan spiritual pasien dengan cara menyentuh pasien dan langsung mebacakan doa, mereka membacakan doa dengan cara mengucapkan apa yang mereka percaya didalam agama budha. Menurut Friedman (2014) Tuhan, doa, dan iman adalah cara untuk mengatasi suatu penyakit. Anggota keluarga yang memiliki agama dan dekat dengan Tuhannya tentunya akan memberikan dukungan spiritual kepada anggota yang laiinya (Santosa, 2012). Di samping itu, faktor lain yang mempengaruhi spiritualitas seseorang adalah keluarga, latar belakang etnik budaya, pengalaman hidup sebelumnya, krisis dan perubahan, terpisah dari ikatan spiritual, isu moral terkaid terapi dan asuhan keperawatan yang kurang sesuai (Friedman, 2013). Karakteristik agama sesuai dengan penelitian yang dilakukan oleh Chusmeyawati (2016) menyatakan bahwa faktor spiritual atau agama merupakan tuntutan untuk menjalani kehidupan, berinteraksi dengan lingkungan sekitar dan kemampuan mencapai harapan hidup. Kebanyakan responden pada pemenuhan kebutuhan spiritual pada pasien mayoritas menunjukkan bahwa dari 30 responden diperoleh mayoritas suami/istri 13 (43,3\%). Pemberian dukungan spiritual merupakan salah satu peran keluarga dalam memberikan pelayanan pada pasien. Kelurga harus berupaya membantu memenuhi kebutuhan spiritual pasien sebagai bagian dari kebutuhan menyeluruh pasien. Dukungan spiritual yang diberikan keluarga dalam pemenuhan kebutuhan spiritual akan meningkatkan spiritual pasien (Hamid, 2008). Hal tersebut didukung oleh Chan (2009) yang mengungkapkan bahwa adanya dukungan spiritual yang dilakukan perawat dapat memotivasi pasien untuk menjalankan kegiatan ibadahnya sesuai dengan keyakinannya masing-masing.

\section{Simpulan}

Dukungan keluarga dalam pemenuhan kebutuhan spiritual yang dapat dilakukan keluarga pada pasien adalah memberikan motivasi dengan mengajarkan dan mengingatkan pasien untuk melaksanakan ibadah berdoa pada saat jam sholat. Keluarga berdoa memberikan rasa damai, tenang, dan membantu proses kesembuhan.

\section{Daftar Pustaka}

Balboni, T., Balboni, M., Enzinger, A., Gallivan, K., Elizabeth, P., \& Wright, A. (2013). Provision of Spiritual Support to Patient With Advanced Cancer by Religious Communities and Associations With Medical Care at the End of Life.

Bussing, A., Balzat, H.,\& Heuseser,P. (2010). Spiritual needs of patients with chronic pain diseases and cancer-validation of the spiritual needs questionnaire. Eur J med Res. 2010,15,266-273

Guillory,J.A.,Sowell,R.,Moneyham L., \& Seals,B. (1997).An exploration of the meaning and use of spirituality among women with HIV/AIDS. Alternative Therapy health medicine,3 (5),55-60.

Friedman, M. M. (2013). Buku Ajar Keperawatan Keluarga: Riset, Teori dan Praktik. Jakarta: EGC

Hamid,AS . (2009) Bunga rampai asuhan keperawatan kesehatan Jiwa. Jakarta : Penerbit Buku kedokteran EGC.

Notoatmodjo. (2010). Metodologi Penelitian Kesehatan. Jakarta : Rineka Cipta. Diakses pada tanggal 15 Juni 2017.

Potter,Patricia A, Anne G. Perry.2010. Fundamentals Of Nursing (Edisi Buku 2). Penerbit: Selemba Medika 
Perry \& Potter. 2012. Buku Ajar Fundamental Keperawatan Edisi 4 Volem 1.Penerbit. EGC

Patricial Gauntlet Beare Micky Stanley. 2012. Buku Ajar Keperawatan Gerontik. Edisi 2. Jakarta:EGC

Rahmawati, I. (2015). Peran Keluarga Dalam Pemenuhan Kebutuhan Spiritual Pada Pasien Yang Dirawat di Ruang ICU RSUD Dr.Pirngadi Medan. http://repository.usu.ac.id/handle/ Diakses pada tanggal 8 juni 2017.

Sriyono. 2019. Promoting Spiritual Nursing Care in an Intensive Care Unit: A Systematic Review. Indian Journal of Public Health Research \& Development, Volume : 10 , Issue : 8 .

Tuti, dkk. 2015. Perbedaan kesejahteraan spiritual pasien bedah jantung di RSHS Bandung.

Ellison Marshall. The Spiritual Well-Being Scale Lori L. University, (Jurnal 1.1 2010). Ellisonl@Marshall.Edu

Yani S.Achir F. Hamid, MN,Dnsc. 2010. Bunga Rampai Asuhan Keperawatan Kesehatan Jiwa. Jakarta EGC. 